\title{
Who shall inherit the seeds of the earth?
}

"Seeds of the Earth", the study recently released by the London-based International Coalition for Development Action (ICDA), raised several issues of international concern. The study's author P R Mooney predicts that the Green Revolution is now moving into its second phase - a dangerous phase in which the responsibility of plant breeding is largely being left to the large private multinational companies. The study contends that new legislation in the developed countries which gives patent-equivalent protection to producers of new varieties of plants is helping the multinational corporations to acquire dominance over the seed market.

These trends are dangerous, according to the ICDA study, because of the gradual erosion of the world's plant genetic resources that is taking place all across the Third World. This erosion process has been accelerated in the last decade by the Green Revolution which has helped to bring vast areas under cultivation of monocultures. Deforestation is another aggravating factor. The Vavilov centres of genetic diversity (see map) - the geographical regions from which plant breeders draw a large part of their germplasm - are mainly located in the Third World. This germplasm is vital to the future food supply systems of mankind, as it is needed by plant breeders for further improvement of crop yields and incorporation of other desirable characteristics such as disease and pest resistance.

'Seeds of the Earth' points out that private corporate interests which are entering the seeds business are building up private gene banks to which access is limited only to the companys' plant breeders. This situation is particularly ironical for Third World plant breeders as Third World countries are the original suppliers of these plant resources.

Little is known about private germplasm collections, but the study does claim that "in some crops a single enterprise dominates total world germplasm holdings". "The FAC reports", says the study, "that one company, United Brands (formerly United Fruit), has about twothirds of the world's banana germplasm in storage". Some public gene banks have had difficulty in obtaining information from private companies about the quantity of type of genetic material they hold.

At the international level, germplasm conservation is the responsibility of the International Board for Plant Genetic Resources which is based in Rome within the Food and Agriculture Organisation of the United Nations. The board coordinates the regional germplasm collection work that is being undertaken by the eight existing international crop research stations. There are also some $\overrightarrow{60}$ nationally-controlled gene banks. The germplasm collection work is massive and the board's activities remain clearly underfunded. There is little germplasm collection work being undertaken by Third World governments themselves, whose plant heritage is immediately threatened.

The ICDA study, therefore, recommends the creation of an annual emergency budget of US $\$ 100$ million for the collection and storage of genetic material and creation of biosphere reserves. But equally important, the study points out, is the step that the UN should take to declare plants as "resources of common heritage to all peoples". There should be no form of legislation that allows exclusive control over plants. Secondly, the study recommends that the genetic material collected should be stored in the developing country from where it is collected. Most of the germplasm being collected at the moment is stored in the developed countries. If this trend continues, the Third World, the original supplier of this vital resource, could soon find itself dependent on the developed countries for the basic material required for its own plant breeding programmes.

The immediate target of attack of the ICDA study is the new legislation that is pending in several developed countries. This legislation provides patent-like protection to new plant varieties. It is the opportunities provided by this type of legislation - often called legislation for "plant breeders' rights" - that has encouraged the entry of big corporate interests, much to the detriment of the small breeders who are now being squeezed out of the market or being bought up. The ICDA study, in fact, claims to have been born out of the movement that farmers in Saskatchewan province of Canada have launched against the pending Canadian bill on plant breeders' rights.

Unfortunately, the study fails to provide adequate evidence for some of the charges

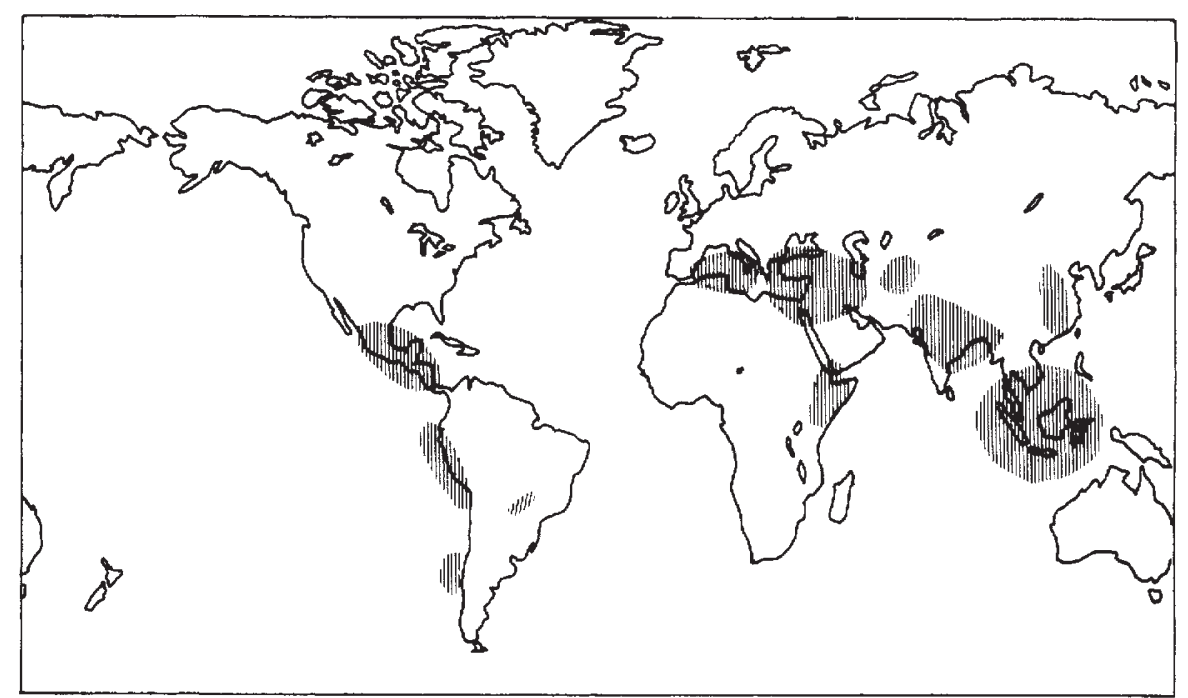

The Vavilov centres of genetic diversity: the Mediterranean, the Near East, Afghanistan, Indo-

Burma, Malaysia-Java, China, Guatemala-Mexico, the Peruvian Andes and Ethiopia.

it makes. For instance, the argument that the entry of agrochemical companies into the seeds business is "a way of assuring that one product line needs the other" remains at the moment a mere hypothesis. Patent protection for many important pesticides that were developed in the 1960s and earlier has already expired or is about to expire. This has raised problems for many companies which are now taking various steps to protect their interests either by diversifying into related areas or by somehow ensuring that their sales are not affected by expiry of patents. As agrochemical companies already have considerable scientific and technical expertise in various branches of agricultural sciences and a good marketing network that reaches right out to the farmers' fields, the seeds business may just be the ideal area in which to diversify.

Similarly, the World Intellectual Property Organisation which is responsible for the International Union for the Protection of New Varieties of Plants (UPOV) believes that the fears raised about the effects of the PBR legislation are exaggerated. An article of the International Convention for the Protection of New Varieties of Plants clearly states that no authorisation is needed to use a protected variety to produce yet another variety - except in the case where "the repeated use of the new variety is necessary for the commercial production of another variety," as in the case of hybrid varieties. Thus, the PBR legislation should not in itself prove to be a major impediment for further plant breeding work.

But despite its deficiencies, there is no doubt that the ICDA study raises several issues of major concern to mankind, and these issues needed to be fully debated to protect public interest, both in the developed and the developing countries.

Anil Agarwal 